\title{
Investigation of Kluyveromyces marxianus as a novel host for large-scale production of porcine parvovirus virus-like particles
}

\author{
Deqiang Yang ${ }^{1,2}$, Lei Chen ${ }^{1,2}$, Jinkun Duan ${ }^{1,2}$, Yao Yu ${ }^{1,2}$, Jungang Zhou ${ }^{1,2^{*}}$ (D) and Hong Lu ${ }^{1,2,3^{*}}$
}

\begin{abstract}
Background: Porcine Parvovirus (PPV) is a Parvovirinae virus that can cause embryonic and fetal loss and death and mummification in affected fetal pigs. Unlike conventional vaccines, virus-like particles (VLPS) inherit the natural structure of their authentic virions and highly immunostimulatory that can induce strong humoral immune and T cell responses with no risk of pathogenicity. The production of PPV VLPs is still a challenge based on traditional expression platforms due to their low yields and high culture costs. Kluyveromyces marxianus is a safe and fast-growing eukaryote that can get high biomass with low-cost cultures. In this study, we investigated the expression and downstream processes of PPV VLPs in K. marxianus, and the potential for effective stand-alone vaccines.
\end{abstract}

Results: After optimization according to the codon bias of $K$. marxianus, the VP2 protein from Kresse strain was highly expressed. In a $5 \mathrm{~L}$ fermentator, the yield of PPV VLPs reached $2.5 \mathrm{~g} / \mathrm{L}$, quantified by HPLC, using a defined mineral medium after $48 \mathrm{~h}$ fermentation. Two strategies were established to purify intracellular PPV VLPs: (i) Using the cation exchange chromatography coupled with Sephacryl ${ }^{\circledR}$ S-500 HR chromatography to purify VLPs from the supernatants of pH adjusted cell lysates. (ii) Using anion exchange chromatography followed by cross-flow diafiltration to recover the VLPs precipitated in pH adjusted cell lysates. The purity of PPV VLPs reached about 95\%, and total recovery was more than $60 \%$. Vaccination of mice with the purified PPV VLPs induced high titers of specific IgG antibodies in sera, and showed hemagglutination inhibitions on both swine and guinea pig erythrocytes. Spleen lymphocyte proliferation and cytokines detection suggested the PPV VLPs produced by K. marxianus provoked the cellular immune and humoral immunity responses in mice.

Conclusions: This is the highest production of recombinant PPV VLPs achieved to date. The superiorities, Generally Recognized As Safe (GRAS), high production, short lead time, and low cost, make K. marxianus a greatly competitive platform for bioproduction of PPV VLPS vaccine.

Keywords: Kluyveromyces marxianus, Porcine parvovirus, Virus-like particles, Vaccine, Immunity

\section{Background}

Parvoviruses are small, non-enveloped DNA viruses belonging to the Parvoviridae taxonomic family and are divided into two subfamilies, the Parvovirinae and the

\footnotetext{
*Correspondence: zhoujg@fudan.edu.cn; honglv@fudan.edu.cn

${ }^{1}$ State Key Laboratory of Genetic Engineering, School of Life Sciences,

Fudan University, 2005 Songhu Road, Shanghai 200438, People's Republic of China

Full list of author information is available at the end of the article
}

Densovirinae, that infects vertebrates and arthropods respectively [1]. In the Parvovirinae subfamily, parvoviruses in the genera Protoparvovirus, Bocaparvovirus, Copiparvovirus and Teraparovirus, were also designated as porcine parvovirus types 1 through 6 [2]. Classic porcine parvovirus (porcine parvovirus type 1, PPV1), newly named Ungulate protoparvovirus 1, was first isolated from a contaminant pig kidney culture in 1965 in Germany [3]. In the past two decades, with the development

(C) The Author(s) 2021. This article is licensed under a Creative Commons Attribution 4.0 International License, which permits use, sharing, adaptation, distribution and reproduction in any medium or format, as long as you give appropriate credit to the original author(s) and the source, provide a link to the Creative Commons licence, and indicate if changes were made. The images or other third party material in this article are included in the article's Creative Commons licence, unless indicated otherwise in a credit line to the material. If material is not included in the article's Creative Commons licence and your intended use is not permitted by statutory regulation or exceeds the permitted use, you will need to obtain permission directly from the copyright holder. To view a copy of this licence, visit http://creativecommons.org/licenses/by/4.0/. The Creative Commons Public Domain Dedication waiver (http//creativecommons.org/publicdomain/zero/1.0/) applies to the data made available in this article, unless otherwise stated in a credit line to the data. 
of molecular biology techniques, six new serotypes of parvovirus have been clinically discovered in pigs, and designated as PPV2 to PPV7 [1]. The PPV7 was first discovered in the USA in 2016 as a new serotype of PPV in the rectal swabs of healthy adult pigs by the metagenomic sequencing technology [4]. PPV was a major causative agent of the swine reproductive failures traditionally summarized as the stillbirth, mummification, embryonic death, and infertility (SMEDI) syndrome [5]. The incidence and severity of symptoms in sows infected with PPV virus depending on the virulence of strains and the time of gestation at which infection occurred [6]. The PPV virus can replicate and be shed from infected sows with no clinical symptoms, but transplacental infections usually result in death and mummification of the fetus before 70 days of gestation, in which fetuses have not developed antibodies to eliminate viruses and survived the infection. Constant infections of PPV in the herd and the inherent high mutation rate gave impetus to the emerging of new mutated strains $[7,8]$. Vaccination against porcine parvovirus can't prevent the virus infection and shedding, but it protects swine from SMEDI diseases [6].

PPV is a negative, single-stranded DNA virus with a genome about 5000 nucleotides, and its mature viron is an icosahedral symmetric particle with approximately $25 \mathrm{~nm}$ in diameter. The genome of PPV contains two large non-overlapping Open Reading Frames (ORFs), the $5^{\prime}$-end ORF, encoding a non-structural protein, and the $3^{\prime}$-end ORF, encoding three structural proteins VP1, VP2 and VP3 [9]. VP1 and VP2 were translated from alternatively spliced mRNA of the 3'-end ORF, while VP3 is a proteolytic product from VP2 by cleaving its $20 \mathrm{~N}$-terminal residues in endosomes [10-12]. PPV capsids consist of 60 equivalent copies of heterotrimer that comprised of three structural proteins, VP1, VP2 and VP3 [13]. The VP2 protein is closely related to the virus-host range and antigenicity, and is generally considered as the major immunoprotective antigen of PPV vaccines, since it contains most of the B-cell epitopes critical to elicit neutralizing antibodies $[14,15]$.

VP2 proteins can spontaneously self-assemble into virus-like particles (VLPs), mimicking the morphology of pathogenic virus and maintaining an identical hemagglutination activity [16]. Recombinant PPV VLPs, first produced by the baculovirus expression vector system (BEVS), elicited high immune response that was identical to a commercial inactivated-virus vaccine [16]. BEVS is one of the most used systems for eukaryotic protein expressions, particularly for proteins that required posttranslational modifications or eukaryotic cellular milieus for proper folding [17]. However, high production costs constrained the extended use of BEVS in production of veterinary vaccines. Except for the BEVS, PPV VP2 has also been expressed in Saccharomyces cerevisiae, Pichia pastoris and Escherichia coli. In S. cerevisiae recombinant VP2 spontaneously assmebled into VLPs intracellularly, but only 8-9 mg VLPs were recovered from one liter of induced yeast culture [18]. Pichia pastoris, another yeast that is widely used for protein expression, produced the $595.76 \mathrm{mg} / \mathrm{L} \mathrm{VP2}$ proteins via secretory expression, but whether VLPs were formed extracellularly remains unknown [19]. E. coli is the most popular bacterial systems of producing recombinant protein, while most of VP2 proteins formed inclusion body after induction even if it was coexpressed with chaperones GroES-GroEL-tig [20].

PPV VLPs are safe and practical alternatives to inactivated infectious viruses as a vaccine that can provoke a strong protective immune response without the risk of diseases and offer a ready platform for facilitating recognition, uptake, and processing by the immune system [21]. As self-assembling proteinaceous nanoparticles, they were also used to deliver epitopes from other viruses. PPV VLPs were modified to display the CD8+T-cell epitope from the lymphocytic choriomeningitis virus (LCMV) nucleoprotein induced strong cytotoxic $\mathrm{T}$ lymphocyte (CTL) responses and completely protected mice against a lethal LCMV infection [15, 22]. Similarly, mice vaccinated with PPV VLPs carrying B and $\mathrm{T}$ cell epitopes from foot-and-mouth disease virus (FMDV) VP1 protein elicited high neutralizing antibody titers against FMDV [23]. However, when PPV VP2 was fused with porcine circovirus 2 (PCV2) immunoreactive epitopes, residues $165-200$ of Cap protein, at its N-terminus, hybrid PPV VLPs formed in HEK-293 cells induced specific antibodies response to both PPV and PCV2 in vaccinated mice [24].

In the current study, we sought to achieve a high production of PPV VLPs using a nonconventional yeast Kluyveromyces marxianus. This strain is an aerobic, Crabtree negative, and homothallic hemiascomycetous yeast that can generate energy from both respiratory metabolism and ethanol fermentation [25-27]. It has been developed for several biotechnological applications, such as the production of enzymes, heterologous proteins, bioingredients, and anticholesterolemic agents, and a host for synthetic biology platform, mainly due to its thermotolerance, high growth rate, broader substrate spectrum and generally recognized as safe (GRAS) [2831]. Using $K$. marxianus, we achieved a $2.5 \mathrm{~g} / \mathrm{L}$ VLPs of the Kresse strain in a $5 \mathrm{~L}$ fermentor. This production is much higher than previous reports. PPV VLPs produced in K. marxianus elicited high titers of IgG antibody and hemagglutination inhibition antibody, and therefore can be used to develop anti-PPV veterinary vaccines. 


\section{Materials and methods}

\section{Strains and plasmids}

Laboratory strain K. marxianus Fim- $1 \Delta U R A 3$ is a uracil auxotroph strain originated from $K$. marxianus Fim-1 deposited in China General Microbiological Culture Collection Center (CGMCC No.10,621 [25]. The vector pUKDN115 was constructed from the pUKD-S-PIT plasmid by replacing the fragment containing an $\alpha$ factor signal peptide sequence and human interferon $\alpha$-2a gene with a multiple cloning site (MCS) [32].

\section{Construction of the recombinant strain}

According to the $K$. marxianus codon preference, the VP2 gene of Kresse strain (GenBank U44978.1) was optimized and synthesized by Genewiz Biotechnology Co., Ltd (Suzhou, China). The optimized VP2 gene was deposited in the NCBI GenBank database under an accession number MT932328. The synthetic VP2 gene was amplified with Phanta ${ }^{\circledR}$ Super Fidelity DNA Polymerase (Vazyme, Nanjing, China) using the following oligonucleotide primers (underlining indicates the homologous sequences from pUKD-N115 vector): 5'-TTTTTT TGTT AGATCCGCGG ATGAGCGAAA ACGTGG AGC-3') and $5^{\prime}$-AGCTTGCGGC CTTAACTAGT CTA GTACAAC TTTCTTGGG-3'. The amplicon was ligated with the EcoR I and Hind III linearized pUKDN115 by Gibson assembly [33], and then directly transformed into the FIM-1 $\triangle U R A 3$ strain according to the Lithium acetate transformation method [34]. Transformants formed on the SD plates $(0.67 \%$ YNB, $2 \%$ glucose, $2 \%$ agar) were verified by PCR using the primers ATGAGCGAAA ACG TGGAGC-3 and CTAGTACAAC TTTCTTGGG-3', and the positive clone was designated to the KM-PPV-VP2 strain.

\section{Expression and identification of the VP2 Protein in $K$. marxianus}

Fresh clones of KM-PPV-VP2 were inoculated in $50 \mathrm{~mL}$ YD medium ( $2 \%$ yeast extract, $4 \%$ glucose) and cultured at $30{ }^{\circ} \mathrm{C}, 220 \mathrm{rpm}$ for $72 \mathrm{~h}$. One milliliter of yeast cells harvested by centrifugation was washed with $1 \mathrm{ml}$ PBS buffer $\left(137 \mathrm{mM} \mathrm{NaCl}, 2.7 \mathrm{mM} \mathrm{KCl}, 10 \mathrm{mM} \mathrm{Na}{ }_{2} \mathrm{HPO}_{4}\right.$, $\left.1.8 \mathrm{mM} \mathrm{KH}_{2} \mathrm{PO}_{4}, \mathrm{pH} 7.4\right)$ twice, and then suspended in $500 \mu \mathrm{l}$ lysate buffer (50 mM HEPS, $140 \mathrm{mM} \mathrm{NaCl}, 1 \mathrm{mM}$ EDTA, 1\% Triton X-100, 0.1\% Na-Deoxycholate, pH 7.5). Approximately $400 \mu \mathrm{l}$ of glass beads (G8772, SigmaAldrich, Missouri, USA) was added to disrupt cells on a Bead-beater (FastPrep-24, MP, California, USA) at $6 \mathrm{~m} / \mathrm{s}$ for $2 \mathrm{~min}$. Cell lysates were centrifuged at $12,000 \mathrm{rpm}$, $4{ }^{\circ} \mathrm{C}$ for $20 \mathrm{~min}$, and supernatants were used for SDSPAGE and Western blotting assays. An anti-PPV VP2 polyclonal antibody and a goat anti-mouse IgG alkaline phosphatase-conjugate (074-1806, KPL, USA) was used as the primary and secondary antibody in western blotting respectively.

\section{Preparation of the anti-PPV VP2 polyclonal antibody}

The native VP2 gene of Kresse strain was cloned into a pET-28a (+) vector within the Sac I and Not I sites ( (Novagen, Madison, USA), generating the pET-28a/VP2 plasmid. After transformation into E. coli BL21(DE3), VP2 protein was induced by $0.2 \mathrm{mM}$ isopropyl- $\beta$-dthiogalactopyranoside (IPTG), and purified by Ni-NTA (Ni Smart Beads, Smart-lifesciences, Changzhou, China) affinity basically as previously described [35]. Six weeks old Balb/C mice, purchased from Beijing Vital River Laboratory Animal Technology Co., Ltd, were immunized with $20 \mu \mathrm{g}$ of purified VP2 antigen mixed with an equal volume of Freund's adjuvant. After 35 days post-immunization (dpi), sera were separated and used as a primary antibody for Western blotting described above.

\section{Transmission Electronic Microscopy (TEM)}

TEM scans of PPV VLPs were performed on a JEM-2100 Electron Microscope (JEOL Tokyo, Japan) according to Bucarey et al. [36]. Briefly, samples were spotted onto carbon-coated copper grids. After adsorption at room temperature for $5 \mathrm{~min}$, copper grids were dried with filters and negatively stained with $3 \%$ of phosphotungstic acid (PTA). The grids were examined at an accelerating voltage of $120 \mathrm{kV}$.

\section{High cell-density fermentation}

High cell-density fermentation was conducted in a $5 \mathrm{~L}$ fermentor (BXBIO, Shanghai, China) as described recently [25]. The KM-PPV-VP2 strain was inoculated in $200 \mathrm{~mL}$ YD medium, grown at $30{ }^{\circ} \mathrm{C}, 220 \mathrm{rpm}$ for $18 \mathrm{~h}$, and then transferred into a fermentor containing $2 \mathrm{~L}$ defined mineral medium [25]. During fermentation, the dissolved oxygen was maintained above $10 \%$, and the temperature was controlled at $30{ }^{\circ} \mathrm{C}$. The $\mathrm{pH}$ was controlled automatically at 5.5 with ammonium hydroxide. At given intervals, $10 \mathrm{ml}$ of culture was harvested to determine the cell density $\left(\mathrm{OD}_{600} \mathrm{~nm}\right)$ and wet cell weight (WCW). For SDS-PAGE analysis of VP2 productions, cell samples were diluted 1:10 with PBS buffer before disruption using the glass bead disruption described above. VLPs quantification was performed on an Agilent Series 1100 System (Agilent, Waldbronn, Germany) using a TSKgel G4000 SWXL column (300 mm $\times$ $7.8 \mathrm{~mm}$ i.d.) (Tosoh Bioscience, Stuttgart, Germany) and 
a TSKgel SWXL guard column $(40.0 \mathrm{~mm} \times 6.0 \mathrm{~mm}$ i.d. $)$ (Tosoh Bioscience) as previously described [37].

\section{Screen of the ion-exchange chromatography (IEX) media} KM-PPV-VP2 cells were collected by centrifugation at $5000 \mathrm{rpm}$ for $10 \mathrm{~min}$, followed by washing with deionized water twice. Rinsed cells were then suspended with PBS buffer pH7.4 for cation exchange, or with $20 \mathrm{mM}$ Tris- $\mathrm{HCl}$ buffer $\mathrm{pH} 8.0$ for anion resins. Cell lysates were prepared by high-pressure homogenization on a JN-02C Homogenizer (JNBIO, Guangzhou, China) under a condition of 1500 bar, $4{ }^{\circ} \mathrm{C}$ for 2 times, followed by centrifugation at $10,000 \mathrm{rpm}, 4{ }^{\circ} \mathrm{C}$ for $30 \mathrm{~min}$. Screens of IEX media were performed on the PolyPrep ${ }^{\circledR}$ Chromatography Columns (Bio-Rad, Hercules, CA, USA) packaged $2 \mathrm{ml}$ of different cation or anion resins listed in Table 1 as described previously [38]. Note that, in case of cation resins, pHs of cell lysates disrupted with PBS buffer should be adjusted to $\mathrm{pH} 4.0$ with acetic acid before centrifugation. After washing with 5 volumes of $20 \mathrm{mM}$ acetate buffer $\mathrm{pH} 4.0$ /Tris- $\mathrm{HCl}$ buffer $\mathrm{pH} 8.0$, bound proteins were eluted by $5 \mathrm{~mL}$ of PBS containing $1 \mathrm{M} \mathrm{NaCl}$, and elutions were analyzed by SDS-PAGE.

\section{Purification of the PPV VLPs}

To purify PPV VLPs by IEX chromatography, yeast cells were suspended in PBS buffer pH7.4 and disrupted by high-pressure homogenization. Cell lysates were subsequently adjusted to $\mathrm{pH}$ 4.0. After centrifugation at $10,000 \mathrm{rpm}, 4{ }^{\circ} \mathrm{C}$ for $30 \mathrm{~min}$, the supernatants of $\mathrm{pH}$ adjusted cell lysate were loaded onto an XK 50/30 column (GE Healthcare) packed with $400 \mathrm{~mL}$ of Capto $\mathrm{S}$ ImpAct resin. Binding VLPs were eluted with $20 \mathrm{mM}$ sodium acetate buffer containing $500 \mathrm{mM} \mathrm{NaCl}$. To elevate the recovery of VLPs, the precipitates of $\mathrm{pH}$

Table 1 lon exchange resins used in this work

\begin{tabular}{llll}
\hline Properties & Resins & Binding conditions & Manufacturers \\
\hline Cation & Capto S ImpAct & $20 \mathrm{mM} \mathrm{NaAc-HAC}$ & GE healthcare \\
& Nuvia S & pH4.0 & Bio-Rad \\
SP Bestarose FF & & Bestchrom \\
Capto MMC & GE healthcare \\
SP HP & Bestchrom \\
CM Sepharose FF & GE healthcare \\
& POROS HS & Life Science \\
& CaptoSP ImpRes & GE healthcare \\
& Nuvia CPrime & & Bio-Rad \\
Anion & Capto Q XP & $20 \mathrm{mM}$ Tris-HCl pH8.0 & GE healthcare \\
& Capto Q & GE healthcare \\
& Q Bestarose FF & Bestchrom
\end{tabular}

adjusted cell lysates were redissolved in an equal volume of $20 \mathrm{mM}$ Tris- $\mathrm{HCl}$ buffer $\mathrm{pH}$ 8.0. Through centrifugation, the clarified supernatant were loaded onto an XK $50 / 30$ column packed with $400 \mathrm{~mL}$ of Capto Q XP resins. After elution with $20 \mathrm{mM}$ Tris- $\mathrm{HCl}$ buffer $\mathrm{pH} 8.0$ plus $500 \mathrm{mM} \mathrm{NaCl}$, fractions were diafiltrated for 10 volumes of PBS on ÄKTA flux (GE Healthcare, USA) equipped with a $750 \mathrm{kDa}$ column (11-0005-50, GE healthcare). Further polishing purification of PPV VLPs was performed on an AKTA Purifier 100 (GE Healthcare, USA) using a HiPrep ${ }^{\text {TM }}$ 26/60 Sephacry ${ }^{\circledR}$ S-500 HR column (GE Healthcare). About $4 \mathrm{ml}$ IEX purified sample was injected and eluted with PBS at a rate of $0.5 \mathrm{~mL} / \mathrm{min}$. Protein concentration was measured by the BCA Protein Assay Kit (23,250, Thermo Fisher Scientific).

\section{Vaccination of mice with PPV VLPs}

Purified VLPs were diluted with PBS buffer and emulsified with MONTANIDE ${ }^{\mathrm{TM}}$ Gel 01 adjuvant (Seppic, Paris, France) at a rate of $10 \%$, giving a final antigen concentration of $240 \mu \mathrm{g} / \mathrm{mL}$. Fifteen of 6-week old female SPF Balb/c mice were randomly divided into 3 groups $(n=5)$. Grouped mice were subcutaneously injected with $20 \mu \mathrm{g}$, $40 \mu \mathrm{g}$ PPV VLPs, and $250 \mu \mathrm{L}$ of PBS as a control, respectively. Blood samples were collected from cheek each week till $49 \mathrm{dpi}$. Sera were separated by incubating blood at $37^{\circ} \mathrm{C}$ for $1 \mathrm{~h}$, followed by centrifugation at $3000 \mathrm{rpm}$ for $4 \mathrm{~min}$, and stored in small aliquots at $-20^{\circ} \mathrm{C}$.

\section{Antibodies detection by enzyme-linked immunosorbent assay (ELISA)}

96-well Costar Assay Plates (Corning, NewYork, USA) were coated with the Ni-NTA purified VP2 protein according to the method described previously [36]. ELISA detections of the anti-PPV IgG titers in mouse sera were performed as described previously by Duan et al. [38].

\section{Serum hemagglutination inhibition $(\mathrm{HI})$ antibody assay} HI antibody titers of serum samples were determined in U-bottom 96-well plates according to the standard method [39]. Briefly, serum samples were inactivated at $56{ }^{\circ} \mathrm{C}$ for $30 \mathrm{~min}$. Before the test, non-specific inhibitors of hemagglutinin in serum samples were removed by treating with $25 \%$ kaolin and $3 \%$ porcine erythrocytes. The treated sera were serially diluted 1:4 with PBS buffer, and each $25 \mu \mathrm{L}$ of serum diluent was mixed with an equal volume of $40 \mu \mathrm{g} / \mathrm{mL}$ purified PPV VLPs. The plates were incubated for $1 \mathrm{~h}$ at $37^{\circ} \mathrm{C}$, and then $50 \mu \mathrm{L}$ of $1 \%$ porcine erythrocyte was added per well. Finally, the plates were incubated at room temperature for $40 \mathrm{~min}$ to calculate 
the HI titers based on the reciprocal of the highest dilution inhibited hemagglutinin completely.

\section{Spleen lymphocyte proliferation and cytokine detection assay}

At $42 \mathrm{dpi}$, three mice from the groups injected with $20 \mu \mathrm{g}$ PPV VLPs and PBS were euthanized to separate spleen lymphocytes in a mouse lymphocyte separation medium (Dakewe, Beijing, China). The separated spleen cells were then cultivated in 96-well plates containing $100 \mu \mathrm{L}$ of 1640 culture medium (Thermo Fisher Scientific, Illinois, USA), at a concentration of $3 \times 10^{6}$ cells $/ \mathrm{mL}$. After adding $0.2 \mu \mathrm{g}$ Concanavalin A (Sigma, MO, USA), the plates were incubated at $37{ }^{\circ} \mathrm{C}$ for $48 \mathrm{~h}$. Proliferative responses were detected using the Cell Titer $96^{\circledR}$ AQueous One
Solution Cell Proliferation Assay Kit (Promega, Madison, WI, USA), and stimulation indexes (SI) were calculated as the ratio of the stimulated sample divided to the unstimulated control at $\mathrm{OD}_{490 \mathrm{~nm}}$. Cytokines secreted by the spleen cells were measured using the Cytometric Bead Array (CBA) Mouse Th1/Th2 Cytokine Kit (Becton Dickinson Biosciences, San Jose, CA, USA).

\section{Results}

\section{Expression of PPV VP2 in K. marxianus}

The VP2 gene of the Kresse strain was used to express in $K$. marxianus, since this PPV strain displayed an increased virulence compared with other virulent strains that could kill immunocompetent fetuses [40]. The native VP2 coding sequence was redesigned for expression

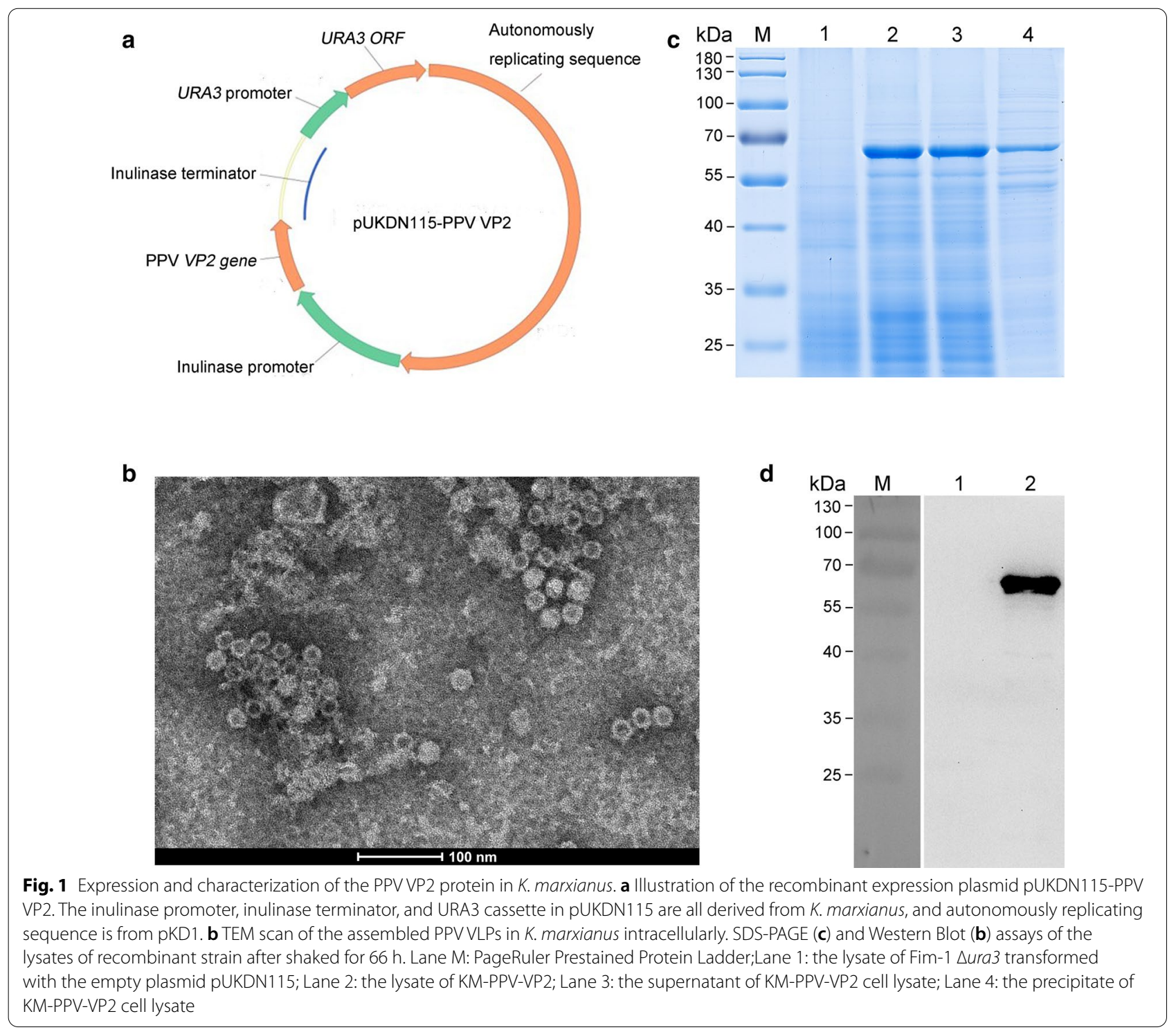


according to the codon usage bias of $K$. marxianus, and then inserted directly downstream of the $K$. marxianus inulinase promoter of the pUKDN115 vector (Fig. 1a). The resulting vector pUKDN115-VP2 was transformed into $K$. marxianus Fim-1 ura3s strain, generating a recombinant strain KM-PPV-VP2. For detection of the expression of VP2 protein, the KM-PPV-VP2 strain was cultured in YD medium for $72 \mathrm{~h}$ and cell lysates were subjected to SDS-PAGE and Western blotting respectively. Compared with Fim-1 ura3 $\Delta$ transformed with the empty pUKDN115 vector, the KM-PPV-VP2 cell lysates contained an additional $65 \mathrm{kDa}$ band, which was consistent with the theoretical molecular weight of VP2 protein (Fig. 1c). This VP2 protein band was further confirmed by Western Blotting with anti-PPV VP2 polyclonal antibody (Fig. 1d).

Previous studies revealed that the recombinant VP2 expressed in insect, eukaryotic or prokaryotic cells formed virus-like particles (VLPs) [16, 18, 19, 41, 42]. To test whether VP2 proteins were spontaneously assembled into VLPs in $K$. marxianus, cell lysates of KM-PPV-VP2 was scanned by TEM, and results confirmed that VP2 proteins were assembled into VLPs with a diameter of approximately $20 \mathrm{~nm}$ in K. marxianus (Fig. 1b).

\section{High production of PPV VLPs in fed-batch fermentation}

Scale-up production of VP2 protein was conducted in a $5 \mathrm{~L}$ reactor using a defined chemical medium. Throughout the fermentation, to achieve a high cell density of the KM-PPV-VP2 strain, glucose was fed at a limited rate to maintain the dissolved oxygen above $10 \%$. After 48 hour fermentation, the cell density $\left(\mathrm{OD}_{600 \mathrm{~nm}}\right)$ reached 560 , with a dry biomass more than $120 \mathrm{~g} / \mathrm{L}$ (Fig. 2a). At certain time points, KM-PPV-VP2 cells were disrupted to detect the expression of VP2 protein by SDS-PAGE. As shown in Fig. 2b, the VP2 began to accumulate intracellularly at $18 \mathrm{~h}$, and at 48 hour the VP2 yield, quantified via SE-HPLC using the purified VLPs as a standard, was approximately $2.5 \mathrm{~g} / \mathrm{L}$.

\section{Screening IEX media to capture PPV VLPs from cell lysates}

To purify PPV VLPs by ion-exchange chromatography, $\mathrm{pH}$ effects on its solubility was investigated before screening of IEX media. Three buffers ranging from $\mathrm{pH}$ 4.0 to 8.0 were used to analyze the solublility of PPV VLPs when disrupting KM-PPV-VP2 cells by highpressure homogenization. As shown in Fig. 3a, almost PPV VLPs existed in the precipitate when using $20 \mathrm{mM}$ acetate buffer $\mathrm{pH} 4.0$, while they became soluble in cases of PBS buffer pH7.4 or $20 \mathrm{mM}$ Tris- $\mathrm{HCl}$ buffer $\mathrm{pH} 8.0$ (Fig. 3a). Therefore, to obtain soluble PPV VLPs and to facilitate downstream purification steps, PBS buffer $\mathrm{pH}$ 7.4 was chose to disrupt the KM-PPV cells. Subsequently, KM-PPV cell lysates disrupted in PBS buffer $\mathrm{pH} 7.4$ were adjusted to $\mathrm{pH} 5.3,4.8,4.3$, and 4.0 with $100 \mathrm{mM}$ acetic acid respectively. SDS-PAGE of these $\mathrm{pH}$ adjusted samples indicated that lowering $\mathrm{pH}$ decreased the solubility of PPV VLPs significantly, with approximately 50\% remained in the precipitate at $\mathrm{pH} 4.0$ (Fig. 3b).

Besides $\mathrm{pH}$ values, 12 cation or anion resins were used to investigated the potentials of them in the purification of PPV VLPs (Table 1). Experimental results were shown in Fig. 4. Among the used cation resins, the Capto S, Nuvia S, and POROS HS resins showed best performances to capture PPV VLPs, with few in the flowthrough fractions, but the SP HP, Nuvia cPrime, SP Bestarose FF, Capto MMC, Capto SP ImpRes, and Capto $\mathrm{Q} X \mathrm{X}$ resins shared relatively weak affinities. However, when using cation CMFF resins or two anion resins, Capto Q and Q Bestarose FF, most of PPV VLPs were
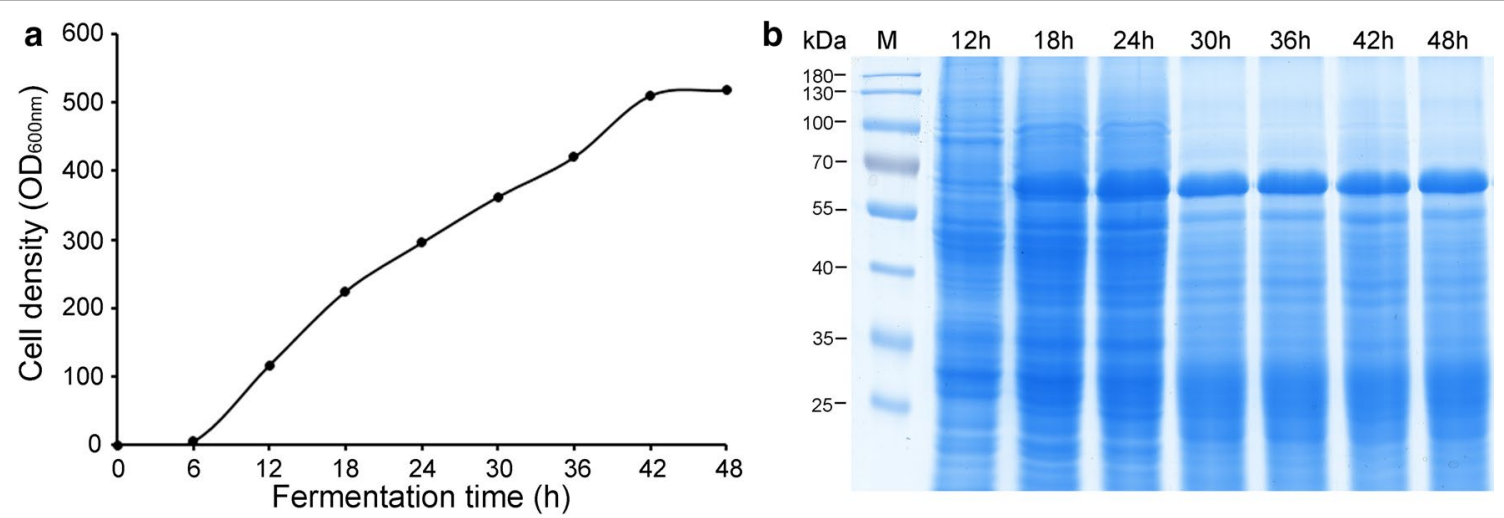

Fig. 2 High cell-density fermentation of the KM-PPV-VP2 strain. a The growth curve of KM-PPV-VP2 in a 5L fermentor. b SDS-PAGE of the VP2 protein expression in KM-PPV-VP2 cell lysates at the indicated time. Yeast cells were collected at an interval of $6 \mathrm{~h}$, and cells cultures were then diluted with PBS at a rate of 1:10. After disruption by high-pressure homogenization, each of $15 \mu \mathrm{l}$ cell lysates was loaded to analyze by SDS-PAGE analysis 


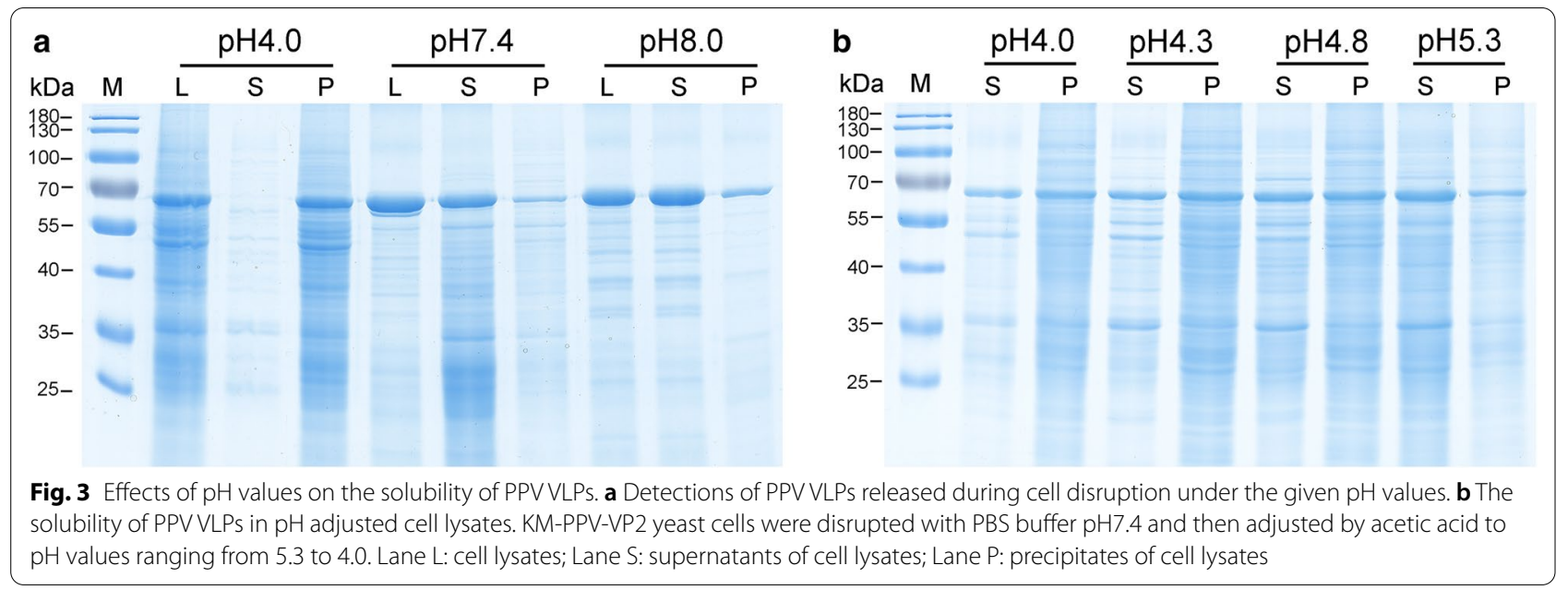

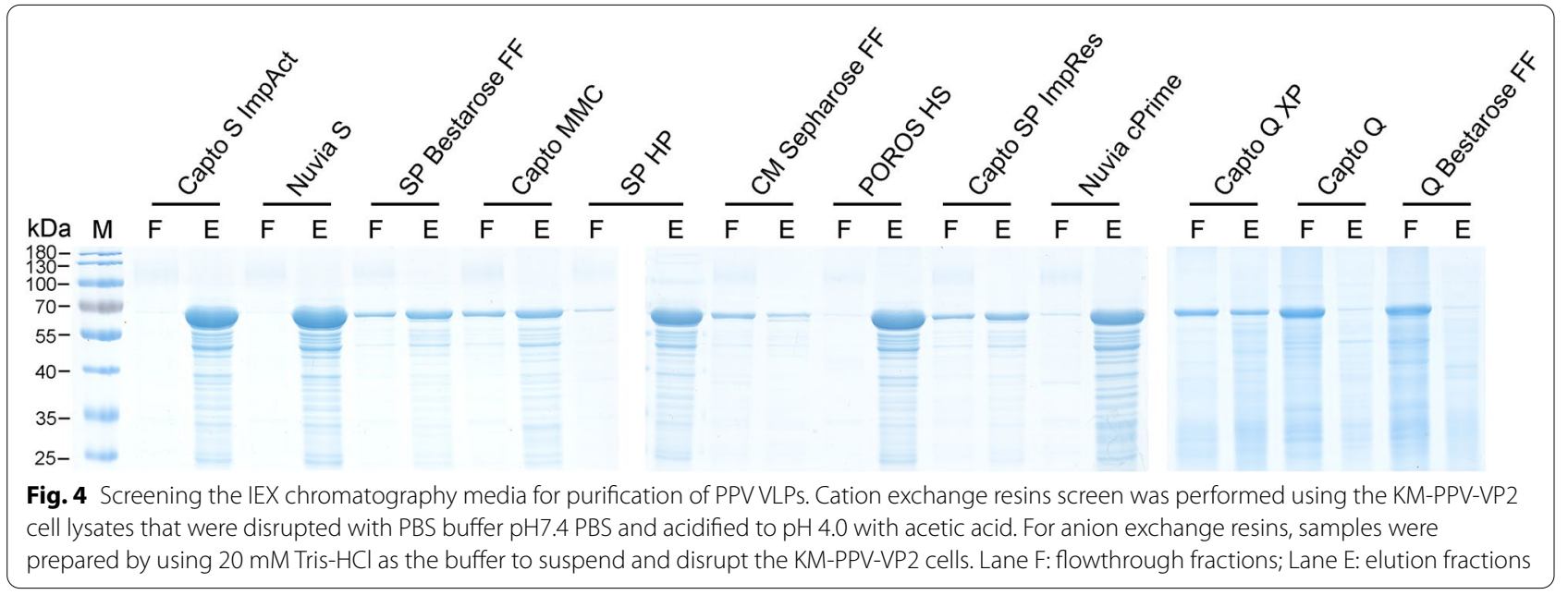

observed in flowthrough fractions, surggesting that these three resins were unsuitable for the IEX purification. Thus, we choose the Capto S ImpAct resin for cation IEX media due to its high binding capacity and good selectivity for PPV VLPs.

Subsequently, the supernatants with different $\mathrm{pHs}$ described above were used to determine the optimal $\mathrm{pH}$ for Capto S ImpAct resins in binding of PPV VLPs. These data were presented in Fig. 5. Overall, PPV VLPs were bound to Capto $\mathrm{S}$ ImpAct resins at a $\mathrm{pH}$ range from 4.0 to 5.3 , but the impurities at $\mathrm{pH} 4.0$ were relatively less than that of other $\mathrm{pHs}$.

\section{Purification of PPV VLPs}

Based on the pHs and resin screens, two steps, the IEX chromatography and Sephacryl ${ }^{\circledR}$ S-500 gel filtration, were set out to purify the PPV VLPs expressed by $K$. marxianus. To facilitate the cation exchange purification

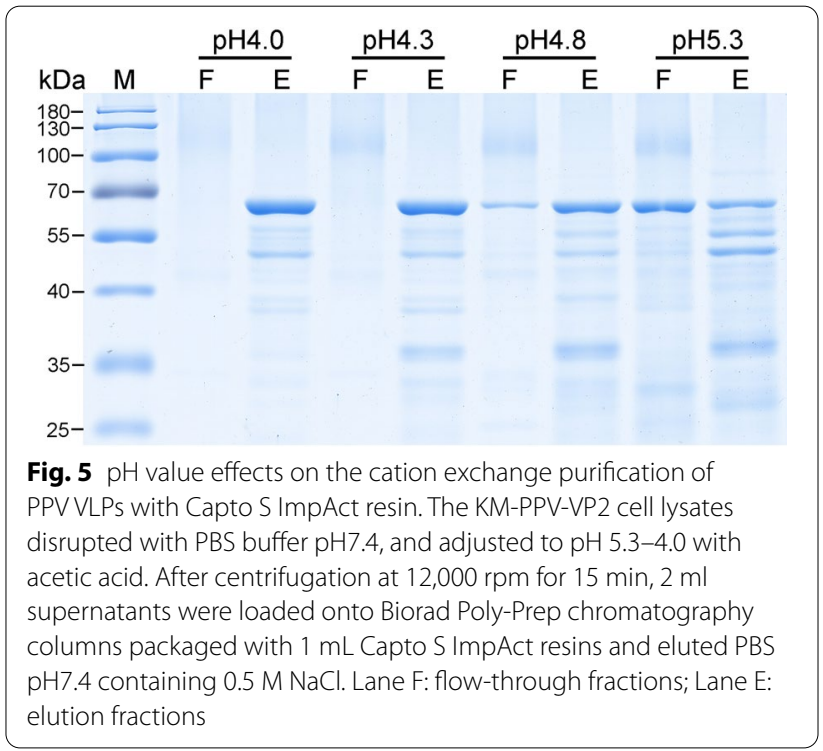


of PPV VLPs, the KM-PPV-VP2 cell lysates were adjusted to $\mathrm{pH} 4.0$ and supernatants was separated for the IEX purification by Capto S ImpAct resins. As a result, about $250 \mathrm{~mL}$ elution fraction containing $2.73 \mathrm{mg} / \mathrm{mL}$ PPV VLPs was obtained from $1 \mathrm{~L}$ fed-batch fermentation cultures (Fig. 6a). The purity of PPV VLPs in the IEX elution fraction reached about $64 \%$, which was detemined by the HPLC method. Thereafter, elution fraction was subjected to a polishing step, Sephacryl ${ }^{\circledR}$ S-500 gel filtration, to remove trace impurities. After two-step purification, the purity of PPV VLPs reached above 95\%, with a recovery of $30 \%$. To confirm the conformation of the purified PPV VLPs, samples collected from the polishing purification step were examined by TEM (Fig. 6b), and results showed that the purified VLPs remained their original shapes.

However, the pH adjustment KM-PPV-VP2 cell lysates resulted that approximately half of PPV VLPs were remained in the precipitates. To recover this part of antigen, we introduced an anion exchange purification process using Capto Q XP resin. The precipitates were suspended with an equal volume of $20 \mathrm{mM}$ Tris $-\mathrm{HCl}$ buffer pH8.0 to the cell lysates to dissolve the precipitated PPV VLPs. After repeat centrifugation, the supernatants were loaded onto an XK 50/30 column packaged Capto Q XP resins. From SDS-PAGE, we found PPV VLPs were almost captured by the anion resins, and the purity of elution was lower than $10 \%$ as analyzed by HPLC (Fig. 7b). HPLC analysis also revealed the main impurities of anion-exchange chromatography were small molecules, whose molecular weights were far smaller than PPV VLPs. Thus, to remove these impurities, the elution fractions were diafiltrated by a crow-flow mode with a $750 \mathrm{kDa}$ column. After that the purity of PPV VLPs reached higher than 95\% (Fig. 7b). Generally, by combination of anion and cation exchange chromatography, the total recovery of PPV VLPs from KM-PPV-VP2 cell lysates increased to above $60 \%$.

\section{Antibody response in the mice}

To investigate the immunogenicity of recombinant PPV VLPs prepared by $K$. marxianus, different doses of purified PPV VLPs antigen that were emulsified with

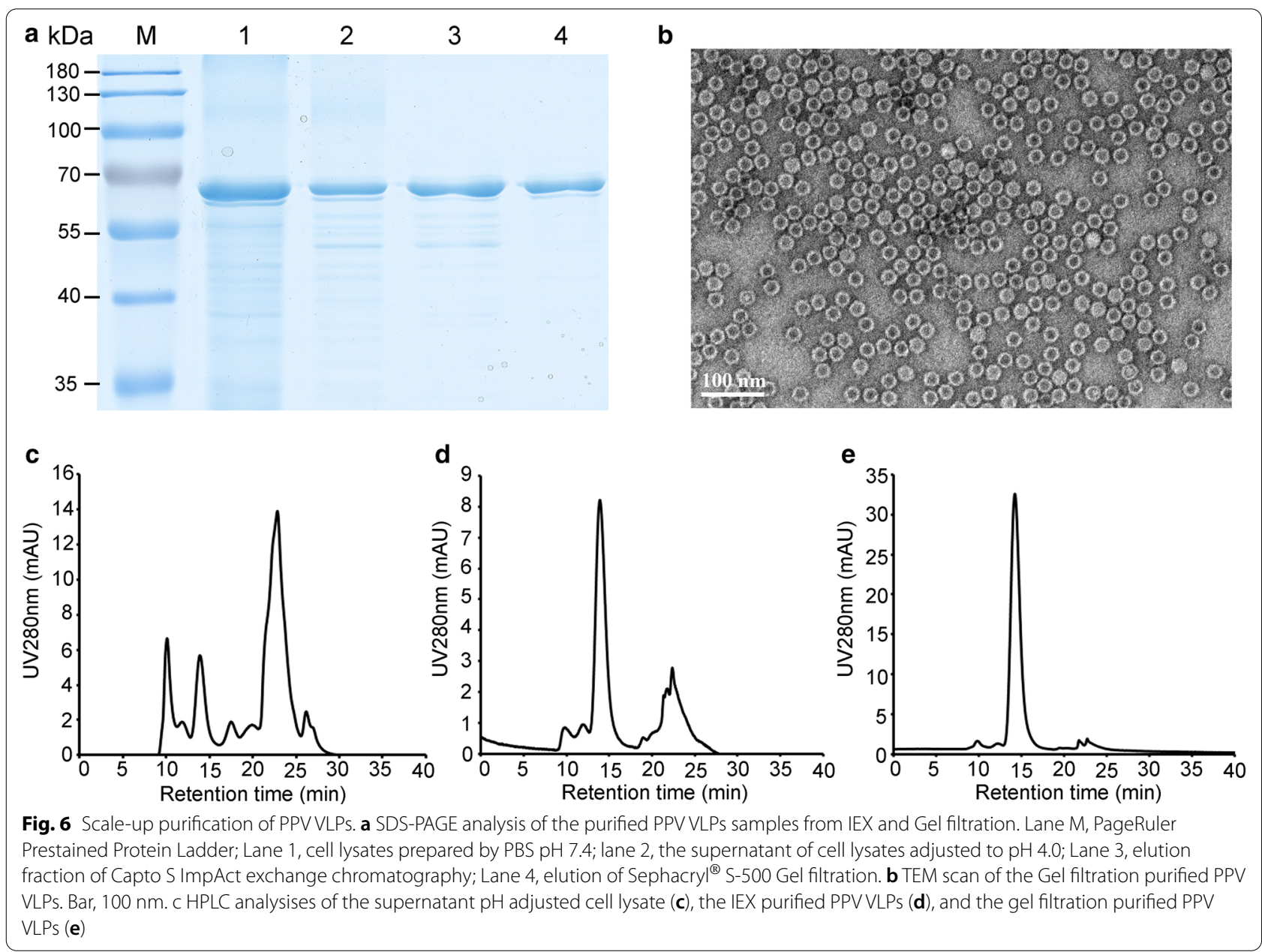



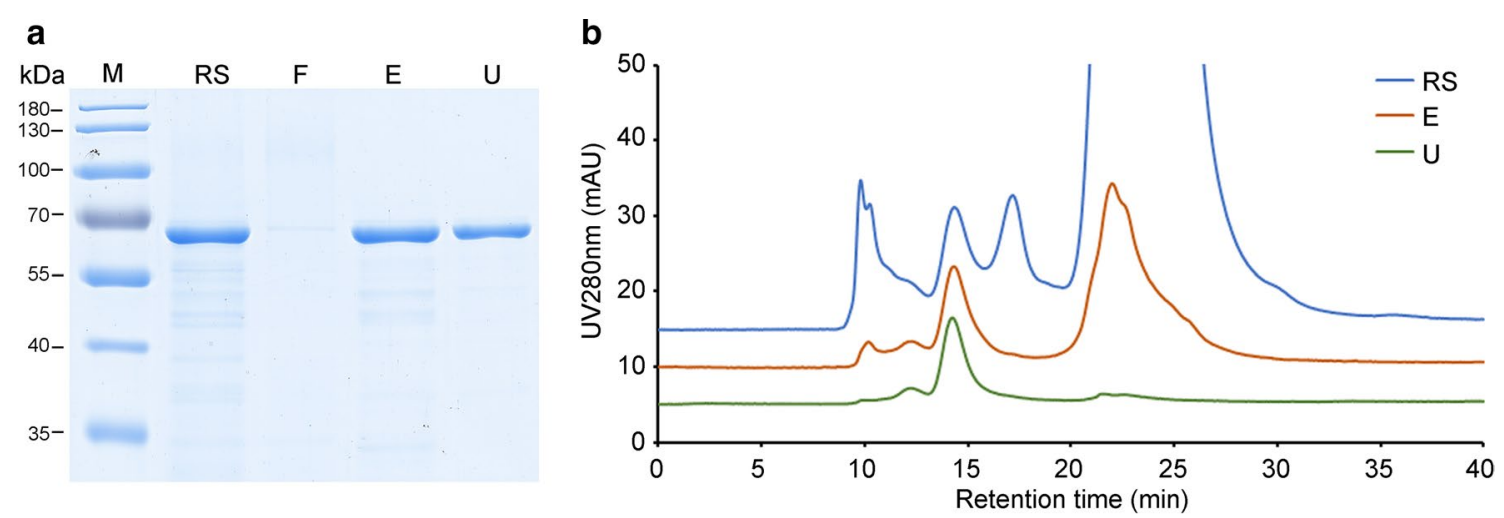

Fig. 7 SDS-PAGE (a) and HPLC (b) assays of the purified PPV VLPs remained in the $\mathrm{pH}$ adjusted precipitates. The precipitates were dissolved using $20 \mathrm{mM}$ Tris-HCl buffer pH 8.0. After clarification by centrifugation, supernatants were loaded onto a Capto Q XP column and PPV VLPS were eluted with $20 \mathrm{mM}$ Tris- $\mathrm{HCl}$ pH 7.4 containing $0.5 \mathrm{M} \mathrm{NaCl}$. Elution fractions were ultrafiltrated with a $750 \mathrm{kDa}$ column in a tangential flow filtration. Lane RS: the redissolved supernatant; Lane F: flowthrough fractions; Lane E: elution fractions; Lane U; the ultrafiltrated VLPs

MONTANIDE $^{\mathrm{TM}}$ Gel 01 adjuvant were subcutaneously injected into SPF Balb/c mice. After $14 \mathrm{dpi}$, mice sera were separated to measure PPV specific antibodies by ELISA assay every 7 days. As shown in Fig. 8a, PPVspecific antibodies were detected in vaccinated mice sera after $14 \mathrm{dpi}$. In both immunized groups, antibody levels increased with the days post-immunization. However, the titers of PPV-specific antibody in mice immunized $40 \mu \mathrm{g}$ antigen were significantly higher than those of $20 \mu \mathrm{g}$, indicating that mice immunized with $40 \mu \mathrm{g}$ of PPV VLPs could effectively produce high-level IgG antibodies.

In the hemagglutination assays, the PPV VLPs derived from Kresse strain showed strong hemagglutination activity on both porcine and guinea pig erythrocytes. Assays for hemagglutination inhibition activities of immunized mice sera were then conducted with $40 \mu \mathrm{g} /$ $\mathrm{mL}$ purified VLPs and serially diluted porcine/guinea pig erythrocytes. After just immunized for $14 \mathrm{dpi}$, the $2 \log$ titers of HI reached around 6 for the PPV specific antibodies, while the mice sera injected with PBS could not inhibit the aggregation of PPV VLPs on pig blood cells (Fig. 8b). After $28 \mathrm{dpi}$, HI titers in nearly all mice rose to values about 8 .

\section{Spleen lymphocyte proliferation and cytokine detection} The spleen lymphocytes isolated from mice after $42 \mathrm{dpi}$ showed promptly response to conA stimulation in vitro proliferation and consequently giving a higher SI than the negative control group (Fig. 8c). This result indicated that PPV VLPs acted as strong immunogen to provoke the cellular immune responses. At the same time, to investigate the induction of humoral immunity spleen lymphocytes we opted to detect the levels of cytokines IL-2, IL-4, IL-5 and TNF- $\alpha$ in spleen lymphocytes cultures after stimulation for $72 \mathrm{~h}$. On average, all the tested cytokines, including IL-2, IL-4, IL-5 and TNF, were higher in immunized spleen lymphocyte cultures than those of PBS groups (Fig. 8d). These results suggested that PPV VLPs produced by $K$. marxianus could induce good humoral immunity as well.

\section{Discussion}

The commercially available PPV vaccines are inactivated whole-virus and live-attenuated vaccines. Irrespective of safety risks such as incomplete inactivation and reversion to virulence, albeit small probability, there are intrinsic disadvantages involved with the administration of inactivated or attenuated vaccines that it hampered to discriminate the differentiation of infected from vaccinated animals (DIVA) in seropositive animals [43]. Intrigued by the inherently safe vaccine and useful epitope carrier nanoparticles [15], we developed $K$. marxianus as a new platform for the production of VLPs. In previous study, we efficiently produced virus-like particles of porcine circovirus (PCV) type 2 by expressing the capsid Cap protein in K. marxianus [38]. However, PCV is one of the smallest animal viruses and its Cap protein is only $28 \mathrm{kDa}$ in size. To investigate the potential and versatility of $K$. marxianus to express large capsid protein, assembly of large capsids, and production of different VLPs, the PPV VP2, may be among the largest capsid protein of known viruses, was used to express in our $K$. marxianus strain. Attribute to high growth rate and facile high biomass, the recombinant $K$. marxianus strain produced $2.5 \mathrm{~g} / \mathrm{L}$ PPV VLPs after just a $48 \mathrm{~h}$ fermentation. As a comparison, the production level of VLPs in Pichia pastoris, E. coli, S. cerevisiae is $595.76 \mathrm{mg} / \mathrm{L} \mathrm{[19],} 15 \mathrm{mg} / \mathrm{L}$ [35], and 8-9 mg/L [18] respectively. Moreover, K. marxianus has a notable advantage over other strains, such as $S$. cerevisiae and E. coli, on high production of VLPs that there 

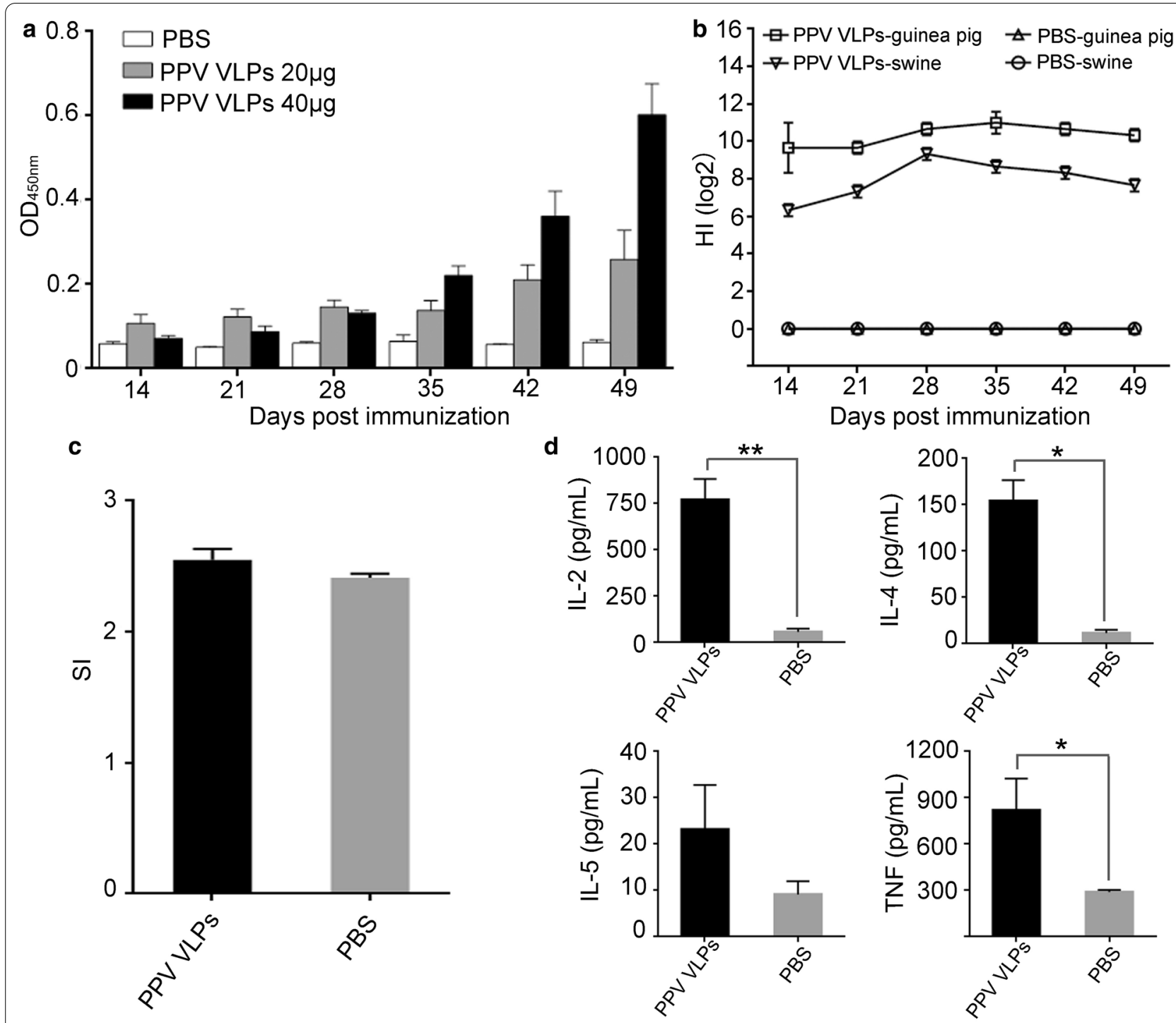

Fig. 8 Immunogenicity assays of the PPV VLPs vaccine. a The titers of anti-PPV IgG in mouse sera immunized with PPV VLPs. Mice in each group $(n=5)$ were immunized with $20 \mu \mathrm{g}$ or $40 \mu \mathrm{g}$ of the PPV VLPs vaccine, and PBS as a control. b the HI antibody titers of mouse immunized with $20 \mu \mathrm{g}$ PPV VLPs. Bars represented mean \pm SEM $(n=5)$. c The stimulation indexes of mouse lymphocytes. At 56 dpi, spleen lymphocytes of the immunized mice and PBS group were isolated and then were stimulated in triplicate with conA. $d$ The levels of cytokines secreted by the mice lymphocytes at 56 dpi. ${ }^{*} P<0.05 ;{ }^{* *} P<0.01$

is no additional inducement during its fermentation since glucose serves as the carbon resources to support cell growth as well as an inducer for its inulinase promoter to obtain high expression of heterologous proteins [25].

As to yeast cells, there is no additional treatment to remove endotoxins, but other downstream operations, such as disrupting the rigid wall of the yeast cells to release VLPs, clarification of cell lysates, and purification processes, are the main factors that significantly increased the production costs overall [44]. In previous studies, the PPV VLPs were commonly purified by sucrose or cesium chloride gradient centrifugation [18, 45], or Ni-NTA affinity chromatography [20, 41], which are not conducive to large-scale production. Aiming to create a simple and low-cost purification process, we assessed the ion-exchange chromatography for purification of PPV VLPs comprehensively. Due to the low isoelectric point of VP2 protein, yeast cell lysates should be acidified to $\mathrm{pH} 4.0$, in order to cationize PPV VLPs and facilitate the anion resins binding. Simultaneously, this treatment could reduce the turbidity of cell lysates apparently, with most of the impurities settled. However, about 
$50 \%$ of VLPs were precipitated during this process. As an alternative strategy to elevate the recovery, we dissolved the precipitated VLPs by $20 \mathrm{mM}$ Tris- $\mathrm{HCl}$ buffer $\mathrm{pH}$ 8.0, in which PPV VLPs are highly soluble, and PPV VLPs were then purified by anion-exchange chromatography coupled with a cross-flow diafiltration. Owing to the first round of charification, most of negatively charged competitors including nucleic acid, polysaccharides, and small molecules in yeast cell lysates were removed, which could decrease the efficiency of Capto Q XP resins in binding of PPV VLPs (Figs. 4 and 7). The purified PPV VLPs from the precipitates gave a purity of $95 \%$, which was comparable to the gel-filtration purification. By this means, less than $40 \%$ of PPV VLPs were lost after these purification processes. These findings provides a new guideline for PPV VLPs purification from intracellular yeast cells.

Currently, most of inactivated or attenuated PPV vaccines were originated from the Cluster A strain NADL-2. The Kresse strain, isolated in the USA in 1985, is the most serious type of PPV-1 that can kill the immunocompetent fetuses [46]. These two strains have a high identity both in sequence and genomic organization, but have quite different pathogenicities [11]. Compared with the NADL-2 strain, three substitutions in VP1/VP2 protein structurally located on the surface of its capsid that may contribute to the highly virulent of PPV Kresse strain [47]. A recent study revealed the genotypes of porcine parvoviruses isolated in South Korea in 2018 was more identical to the ancient Kresse strain. This re-evolution to its original strains may increase the epidemiologic risk of PPV [48]. Additionally, the spread of PPV-27a, a unique virulent cluster $\mathrm{D}$ strain that has a unique immunological feature, raised the concerns about the efficacy of currently used inactivated or attenuated vaccines. A recent report revealed that a "Kresse-like" K22 PPV strain-based vaccine showed stronger protection than the commercial NADL-2 based vaccines in a PPV-27a strain challenge [49]. Enlightened by these, we set out to express the VP2 capsid protein of Kresse strain and produce PPV VLP antigens in our $K$. marxianus expression platform. Another, recombinant VLPs can be easily changed to desired genotype based on a well-established expression platform in a shorter time.

Compared to inactivated PPV vaccines, facile high titers of PPV VLPs elicited better cellular immune responses in gilts, and induced high neutralization antibody and high hemagglutination inhibition antibody in guinea pigs $[20,50]$. When vaccinated with doses of 20-40 $\mu \mathrm{g}$ per mouse PPV VLPs from $K$. marxianus, high titers of specific IgG antibodies were induced in mice. As is known, PPV virus could agglutinate erythrocytes of chicken, guinea pig, mouse, human, monkey, rat, and cat [51]. In our study, sera of mice immunized with Kresse strain VLPs showed high hemagglutination inhibition, a serologic index to the specific antibody of a virus, against either swine or guinea pig erythrocytes, surggested that VLPs produced in K. marxianus maintained the natural morphology of pathogenic virus [52]. But the cause of hemagglutination to swine erythrocytes by the Kresse strain VLPs is unknown. Except for the antibodies, Spleen lymphocyte proliferations and cytokines detection further confirmed that this vaccine has a good immune effect, caused both humoral and cellular immunity. The commercial whole-virus vaccines, based on the nonpathogenic NADL2 strain, protected pigs against PPV disease but do not prevent infection and virus shedding when challenged with an antigenically heterologous strain PPV-27a [6, 51, 53]. Furthermore, an experimental vaccine based on the PPV-27a strain protected the fetuses from vaccinated sows against disease when infected with the homologous PPV strain [54]. These results suggest the PPV VLPs produced in this study can be used to protect swine from porcine parvovirus diseases.

\section{Abbreviations \\ PPV: Porcine parvovirus; SMEDI: Stillbirth, mummification, embryonic death, and infertility; ORFs: Open Reading Frames; VLPs: Virus-like particles; MCS: Multiple cloning sites; IPTG: Isopropyl- $\beta$-d-thiogalactopyranoside; dpi: Days post-immunization; PTA: Phosphotungstic acid; IEX: Ion exchange chromatog- raphy; DIVA: Differentiation of infected from vaccinated animals.}

\section{Authors' contributions}

DY, LC and JZ designed and performed the experiments, analyzed the data and wrote the manuscript. HL and JZ devised the project and supervised the work. JD performed the electron microscopy. YY constructed the plasmid and performed the codon optimization of the VP2 gene. All authors provided critical feedback and helped shape the research, analysis and manuscript. All authors read and approved the final manuscript.

\section{Funding}

This study was supported by the projects of National Natural Science Foundation of China (No. 31970068 and No. 31770094 to HL), and Science and Technology Research Program of Shanghai (No. 18391901800 and No. 19DZ2282100 to $\mathrm{HL}$ ).

\section{Ethical approval and consent to participate}

All mice experimental procedures were approved by the Animal Experiment Committee of Fudan University. All applicable international, national, and institutional guidelines for the care and use of animals were strictly followed.

\section{Consent for publication}

Not applicable.

\section{Competing interests}

The authors declare that they have no competing interests.

\section{Author details}

1 State Key Laboratory of Genetic Engineering, School of Life Sciences, Fudan University, 2005 Songhu Road, Shanghai 200438, People's Republic of China. ${ }^{2}$ Shanghai Engineering Research Center of Industrial Microorganisms, 2005 Songhu Road, Shanghai 200438, People's Republic of China. ${ }^{3}$ Shanghai Collaborative Innovation Center for Biomanufacturing (SCICB), East China 
University of Science and Technology, 130 Meilong Road, Shanghai 200237, People's Republic of China.

Received: 4 September 2020 Accepted: 8 January 2021

Published online: 25 January 2021

\section{References}

1. Cui J, Biernacka K, Fan J, Gerber PF, StadejekT, Opriessnig T. Circulation of Porcine Parvovirus types 1 through 6 in serum samples obtained from six commercial polish pig farms. Transbound Emerg Dis. 2017;64:1945-52.

2. Streck AF, Canal CW, Truyen U. Molecular epidemiology and evolution of porcine parvoviruses. Infect Genet Evol. 2015;36:300-6.

3. Mayr A, Mahnel H. Cultivation of hog cholera virus in pig kidney cultures with cytopathogenic effect. Zentralbl Bakteriol Orig. 1964;195:157-66.

4. Palinski RM, Mitra N, Hause BM. Discovery of a novel Parvovirinae virus, porcine parvovirus 7, by metagenomic sequencing of porcine rectal swabs. Virus Genes. 2016;52:564-7.

5. Mengeling WL, Lager KM, Vorwald AC. The effect of porcine parvovirus and porcine reproductive and respiratory syndrome virus on porcine reproductive performance. Anim Reprod Sci. 2000;60-61:199-210.

6. Jozwik A, Manteufel J, Selbitz HJ, Truyen U. Vaccination against porcine parvovirus protects against disease, but does not prevent infection and virus shedding after challenge infection with a heterologous virus strain. J Gen Virol. 2009;90:2437-41.

7. Streck AF, Bonatto SL, Homeier T, Souza CK, Goncalves KR, Gava D, Canal $\mathrm{CW}$, Truyen U. High rate of viral evolution in the capsid protein of porcine parvovirus. J Gen Virol. 2011;92:2628-36.

8. Boisvert M, Bouchard-Levesque V, Fernandes S, Tijssen P. Classic nuclear localization signals and a novel nuclear localization motif are required for nuclear transport of porcine parvovirus capsid proteins. J Virol. 2014;88:11748-59.

9. Molitor TW, Joo HS, Collett MS. Porcine Parvovirus-virus purification and structural and antigenic properties of virion polypeptides. J Virol. 1983;45:842-54.

10. Ranz Al, Manclus JJ, Diaz-Aroca E, Casal J. Porcine parvovirus: DNA sequence and genome organization. J Gen Virol. 1989;70(Pt 10):2541-53.

11. Bergeron J, Menezes J, Tijssen P. Genomic organization and mapping of transcription and translation products of the NADL-2 strain of porcine parvovirus. Virology. 1993;197:86-98.

12. Farr GA, Cotmore SF, Tattersall P.VP2 cleavage and the leucine ring at the base of the fivefold cylinder control $\mathrm{pH}$-dependent externalization of both the VP1 N terminus and the genome of minute virus of mice. J Virol. 2006;80:161-71.

13. Chapman MS, Rossmann MG. Structure, sequence, and function correlations among parvoviruses. Virology. 1993;194:491-508.

14. Zimmermann P, Ritzmann M, Selbitz HJ, Heinritzi K, Truyen U. VP1 sequences of German porcine parvovirus isolates define two genetic lineages. J Gen Virol. 2006;87:295-301.

15. Sedlik C, Saron MF, Sarraseca J, Casal I, Leclerc C. Recombinant parvoviruslike particles as an antigen carrier: a novel nonreplicative exogenous antigen to elicit protective antiviral cytotoxic T cells. Proc Natl Acad Sci U S A. 1997;94:7503-8.

16. Martinez C, Dalsgaard K, Lopez de Turiso JA, Cortes E, Vela C, Casal Jl. Production of porcine parvovirus empty capsids with high immunogenic activity. Vaccine. 1992;10:684-90.

17. Liu FX, Wu XD, Li L, Liu ZS, Wang ZL. Use of baculovirus expression system for generation of virus-like particles: successes and challenges. Protein Expression Purif. 2013;92:195-5.

18. Tamosiunas PL, Petraityte-Burneikiene R, Lasickiene R, Akatov A, Kundrotas G, Sereika V, Lelesius R, Zvirbliene A, Sasnauskas K. Generation of recombinant Porcine Parvovirus virus-like particles in Saccharomyces cerevisiae and development of virus-specific monoclonal antibodies. J Immunol Res. 2014. https://doi.org/10.1155/2014/573531.

19. Guo $\mathrm{CH}$, Zhong ZM, Huang YM. Production and immunogenicity of VP2 protein of porcine parvovirus expressed in Pichia pastoris. Arch Virol. 2014;159:963-70.

20. Ji PC, Liu YC, Chen YM, Wang AP, Jiang DW, Zhao BL, Wang JC, Chai SJ, Zhou EM, Zhang GP. Porcine parvovirus capsid protein expressed in
Escherichia coli self assembles into virus-like particles with high immunogenicity in mice and guinea pigs. Antiviral Res. 2017;139:146-52.

21. Schwarz B, Douglas T. Development of virus-like particles for diagnostic and prophylactic biomedical applications. Wiley Interdiscip Rev Nanomed Nanobiotechnol. 2015;7:722-35.

22. Rueda P, Martinez-Torrecuadrada JL, Sarraseca J, Sedlik C, del Barrio M, Hurtado A, Leclerc C, Casal Jl. Engineering parvovirus-like particles for the induction of B-cell, CD4(+) and CTL responses. Vaccine. 1999;18:325-32.

23. Pan QX, Wang H, Ouyang W, Wang XL, Bi ZW, Xia XX, Wang YS, He KW. Immunogenicity of adenovirus-derived porcine parvovirus-like particles displaying $B$ and $T$ cell epitopes of foot-and-mouth disease. Vaccine. 2016;34:578-85.

24. Pan QX, He KW, Huang KH. Development of recombinant porcine parvovirus-like particles as an antigen carrier formed by the hybrid VP2 protein carrying immunoreactive epitope of porcine circovirus type 2. Vaccine. 2008;26:2119-26.

25. Zhou J, Zhu P, Hu X, Lu H, Yu Y. Improved secretory expression of lignocellulolytic enzymes in Kluyveromyces marxianus by promoter and signal sequence engineering. Biotechnol Biofuels. 2018;11:235.

26. Blank LM, Lehmbeck F, Sauer U. Metabolic-flux and network analysis in fourteen hemiascomycetous yeasts. FEMS Yeast Res. 2005;5:545-58.

27. van Dijken JP, Weusthuis RA, Pronk JT. Kinetics of growth and sugar consumption in yeasts. Anton Leeuw Int J G. 1993;63:343-52.

28. Fonseca GG, Heinzle E, Wittmann C, Gombert AK. The yeast Kluyveromyces marxianus and its biotechnological potential. Appl Microbiol Biotechnol. 2008;79:339-54.

29. Melanie M, LANE JPM. Kluyveromyces marxianus: a yeast emerging from its sister's shadow. fungal biology reviews. 2010;24:17-24.

30. Rodicio R, Heinisch JJ. Yeast on the milky way: genetics, physiology and biotechnology of Kluyveromyces lactis. Yeast. 2013;30:165-77.

31. Cernak P, Estrela R, Poddar S, Skerker JM, Cheng YF, Carlson AK, Chen B, Glynn VM, Furlan M, Ryan OW, et al: Engineering Kluyveromyces marxianus as a Robust Synthetic Biology Platform Host. Mbio 2018, 9.

32. Cai XP, Zhang J, Yuan HY, Fang ZA, Li YY. Secretory expression of heterologous protein in Kluyveromyces cicerisporus. Appl Microbiol Biotechnol. 2005;67:364-9.

33. Gibson DG, Young L, Chuang RY, Venter JC, Hutchison CA, Smith HO. Enzymatic assembly of DNA molecules up to several hundred kilobases. Nat Methods. 2009;6:343-U341.

34. Antunes DF, de Souza CG, de Morais MA. A simple and rapid method for lithium acetate-mediated transformation of Kluyveromyces marxianus cells. World J Microbiol Biotechnol. 2000;16:653-4.

35. Sistigu A, Bracci L, Valentini M, Proietti E, Bona R, Negri DR, Ciccaglione AR, Tritarelli E, Nisini R, Equestre M, et al. Strong CD8 + T cell antigenicity and immunogenicity of large foreign proteins incorporated in HIV-1 VLPS able to induce a Nef-dependent activation/maturation of dendritic cells. Vaccine. 2011;29:3465-75.

36. Bucarey SA, Noriega J, Reyes P, Tapia C, Saenz L, Zuniga A, Tobar JA. The optimized capsid gene of porcine circovirus type 2 expressed in yeast forms virus-like particles and elicits antibody responses in mice fed with recombinant yeast extracts. Vaccine. 2009;27:5781-90.

37. Steppert $P$, Burgstaller D, Klausberger M, Tover A, Berger E, Jungbauer A. Quantification and characterization of virus-like particles by size-exclusion chromatography and nanoparticle tracking analysis. J Chromatogr A. 2017;1487:89-99.

38. Duan J, Yang D, Chen L, Yu Y, Zhou J, Lu H. Efficient production of porcine circovirus virus-like particles using the nonconventional yeast Kluyveromyces marxianus. Appl Microbiol Biotechnol. 2019;103:833-42.

39. Joo HS, Donaldson-Wood CR, Johnson RH. A standardised haemagglutination inhibition test for porcine parvovirus antibody. Aust Vet $\mathrm{J}$. 1976;52:422-4.

40. Choi CS, Molitor TW, Joo HS, Gunther R. Pathogenicity of a skin isolate of porcine parvovirus in swine fetuses. Vet Microbiol. 1987;15:19-29.

41. Zhou H, Yao G, Cui S. Production and purification of VP2 protein of porcine parvovirus expressed in an insect-baculovirus cell system. Virol J. 2010;7:366

42. Ji P, Liu Y, Chen Y, Wang A, Jiang D, Zhao B, Wang J, Chai S, Zhou E, Zhang G. Porcine parvovirus capsid protein expressed in Escherichia coli selfassembles into virus-like particles with high immunogenicity in mice and guinea pigs. Antiviral Res. 2017;139:146-52. 
43. Draper SJ, Heeney JL. Viruses as vaccine vectors for infectious diseases and cancer. Nat Rev Microbiol. 2010;8:62-73.

44. Morenweiser R. Downstream processing of viral vectors and vaccines. Gene Ther. 2005;12(Suppl 1):103-10.

45. Antonis AF, Bruschke CJ, Rueda P, Maranga L, Casal Jl, Vela C, Hilgers LA, Belt PB, Weerdmeester K, Carrondo MJ, Langeveld JP. A novel recombinant virus-like particle vaccine for prevention of porcine parvovirusinduced reproductive failure. Vaccine. 2006;24:5481-90.

46. Bergeron J, Hebert B, Tijssen P. Genome organization of the Kresse strain of porcine parvovirus: identification of the allotropic determinant and comparison with those of NADL-2 and field isolates. J Virol. 1996;70:2508-15.

47. Simpson AA, Hebert B, Sullivan GM, Parrish CR, Zadori Z, Tijssen P, Rossmann MG. The structure of porcine parvovirus: comparison with related viruses. J Mol Biol. 2002;315:1189-98.

48. Oh WT, Kim RY, Nguyen VG, Chung HC, Park BK. Perspectives on the evolution of Porcine Parvovirus. Viruses. 2017;9:196.

49. Kiss I, Kovacs E, Zadori Z, Meszaros I, Csagola A, Bajnoczi P, Mortensen $P$, Palya V. Vaccine protection against experimental challenge infection with a PPV-27a genotype virus in pregnant gilts. Vet Med (Auckl). 2020;11:17-24.

50. Tian W, Qiu Z, Cui YC, Zhang J, Ma XJ, Cui SJ, Zheng SM. Comparison of immune responses induced by porcine parvovirus virus-like particles and inactivated vaccine. Pak J Pharm Sci. 2019;32:377-82.
51. Meszaros I, Olasz F, Csagola A, Tijssen P, Zadori Z. Biology of Porcine Parvovirus (Ungulate parvovirus 1). Viruses. 2017;9:393.

52. Visseaux B, Collin G, Ichou H, Charpentier C, Bendhafer S, Dumitrescu M, Allal L, Cojocaru B, Desfrere L, Descamps D, et al. Usefulness of multiplex PCR methods and respiratory viruses' distribution in children below 15 years old according to age, seasons and clinical units in France: A 3 years retrospective study. PLoS One. 2017;12:e0172809.

53. Paul PS, Mengeling WL. Evaluation of a modified live-virus vaccine for the prevention of Porcine parvovirus-induced reproductive disease in swine. Am J Vet Res. 1980;41:2007-11.

54. Foerster T, Streck AF, Speck S, Selbitz HJ, Lindner T, Truyen U. An inactivated whole-virus porcine parvovirus vaccine protects pigs against disease but does not prevent virus shedding even after homologous virus challenge. J Gen Virol. 2016;97:1408-13.

\section{Publisher's note}

Springer Nature remains neutral with regard to jurisdictional claims in published maps and institutional affiliations.
Ready to submit your research? Choose BMC and benefit from:

- fast, convenient online submission

- thorough peer review by experienced researchers in your field

- rapid publication on acceptance

- support for research data, including large and complex data types

- gold Open Access which fosters wider collaboration and increased citations

- maximum visibility for your research: over $100 \mathrm{M}$ website views per year

At BMC, research is always in progress.

Learn more biomedcentral.com/submissions 